\title{
Yield and Economic Results of Spring Barley Grown in Crop Rotation and in Monoculture
}

\author{
Andrzej Woźniak ${ }^{1}$, Anna Nowak ${ }^{2 *}$, Małgorzata Haliniarz ${ }^{1}$, Dorota Gawęda ${ }^{1}$ \\ ${ }^{1}$ Department of Herbology and Plant Cultivation Techniques, University of Life Sciences in Lublin, Poland \\ ${ }^{2}$ Department of Economics and Agribusiness, University of Life Sciences in Lublin, Poland
}

Received: 22 March 2018

Accepted: 29 April 2018

\begin{abstract}
The study aimed to evaluate the yield and economic effectiveness of spring barley grown in crop rotation and cereal monoculture under three tillage systems. The experimental factors were crop sequence systems: 1) crop rotation (peas - spring barley - winter wheat) and 2) cereal monoculture (spring barley - winter wheat - winter wheat) and tillage systems: a) conventional tillage (CT), b) reduced tillage (RT), and 3) herbicide tillage (HT). Spring barley grain yield was significantly higher in crop rotation than in cereal monoculture. Also, yield was significantly higher under RT than under CT and HT. The number of weeds per $\mathrm{m}^{-2}$ in cereal monoculture was significantly higher than in crop rotation. Also, more weeds occurred under RT than under CT and HT. Air-dry weight of weeds was higher in cereal monoculture than in crop rotation and it was also higher under RT than under CT. In crop rotation, for each tillage system the production value $\left(E U R h^{-1}\right)$ was higher than in monoculture, whereas the highest production value $\left(E \mathrm{ER} \mathrm{ha}^{-1}\right)$ was achieved in crop rotation in RT sites. The economic analysis showed a clear competitive advantage of RT sites with crop rotation over other sites. The proof is the highest gross margin and income from activity, and the lowest unit cost of production.
\end{abstract}

Keywords: yield, crop sequence, tillage system, economic results, gross margin

\section{Introduction}

Crop rotation is a factor integrating all elements of agricultural engineering, that is, tillage, organic and mineral fertilizers, and crop protection. It has a positive effect on the productivity and quality of crops [1-2], economic results [3], and health status of crops [4], as well as biological and chemical properties of soil [5]. Unfortunately, naturally correct crop rotation composed of root crops, leguminous plants, and other non-cereal

*e-mail: anna.nowak@up.lublin.pl crops occurs more and more rarely. Instead, reduced sequencing of crops is practised, consisting mainly of cereals and rape. An exception is ecological farms with integrated agricultural production in which catch crops, long-term leguminous plants are grown, and organic fertilizers are used [6-7]. Tillage systems also have a significant influence on crop yield [8]. Depending on the type of crop rotation and the crops grown, soil and climatic conditions as well as technical resources of the farm and different tillage systems are adopted, i.e., plough tillage, reduced tillage, direct seeding, and strip-till, along with their modifications [9]. The crop sequence in crop rotation, tillage system, and habitat conditions have an aggregate effect, thus they each 
affect crop yield to a different extent [10]. De Vita et al. [11] and Montemurro and Maiorana [12] demonstrated that in hot and dry regions no-plough tillage gives better yield than conventional tillage, and in moderately humid conditions better production effects are obtained under conventional tillage rather than no-plough tillage [9]. Cereal monoculture leads to numerous occurrences of weeds and in particular to compensation of a few species that are highly competitive in relation to grains [7, 13]. However, effective elimination of such weeds from sown grains requires high expenditure on pesticides [14]. Another problem connected with cereal monocultures is diseases caused by a complex of foot rot pathogens and pests. Maintaining these agrophages within the acceptable economic injury levels also requires multiple applications of pesticides [14]. In crop rotation the occurrence of weeds, fungal pathogens, and pests is to a large extent reduced by the sequence of crops from different biological groups, catch crops, differentiated agricultural techniques, and the application of pesticides from different groups of chemicals. Thus, the number of plant protection treatments can be reduced, which has a positive effect on the natural environment and economic effects [3, 15-16].

Our studies aimed at evaluating the yield and economic results of spring barley sown in crop rotation and monoculture under different tillage systems.

\section{Materials and Methods}

\section{Location and Plan of the Experiment}

The field experiment started in 2009 on the Uhrusk Experimental Farm $\left(51^{\circ} 18^{\prime} \mathrm{N}, 23^{\circ} 36^{\prime} \mathrm{E}\right)$ owned by the University of Life Sciences in Lublin (southeastern Poland), whereas the results presented in this paper date back to 2015-2017. The experiment was based on split blocks of $6 \times 25 \mathrm{~m}$, and was performed in 3 replications, whereas the factors were cropping systems: 1) crop rotation: peas - spring barley winter wheat; and 2) cereal monoculture: spring barley - winter wheat - winter wheat. The other factor was tillage systems: a) conventional tillage (CT), b) reduced tillage (RT), and 3) herbicide tillage (HT). In CT, shallow ploughing (10-12 cm deep) and deep pre-winter ploughing $(25-30 \mathrm{~cm})$ were performed for spring barley. In RT, both ploughings were replaced with double tilling, and in HT only glyphosate (4 $\left.\mathrm{L} \mathrm{ha}^{-1}\right)$ was used. In spring the only procedure was harrowing and a tillage set was used under CT, whereas under RT and HT tilling was performed and a tillage set was used.

\section{Habitat Conditions}

Experimental soil was Rendzic Phaeozem [17], composed of sandy clay with $24.3 \%$ loamy intrusions and $13.5 \%$ dusty intrusions, alkaline reaction $\left(\mathrm{pH}_{\mathrm{kCL}}=7.3\right)$, high content of assimilable forms of phosphorus (120 mg $\mathrm{P} \mathrm{kg} \mathrm{kg}^{-1} \mathrm{~d} . \mathrm{m}$.) and potassium (217 $\mathrm{mg} \mathrm{K} \mathrm{kg}^{-1}$ ), and low content of magnesium (71 $\mathrm{mg} \mathrm{Mg} \mathrm{kg}^{-1}$ ). In the multi-year period (1963-2013) the annual precipitation total in the analyzed area was above $600 \mathrm{~mm}$, including $381 \mathrm{~mm}$ in the period from spring barley sowing to harvesting (from March until August). In the study years (2015-2017) monthly precipitation totals from March until August were considerably differentiated - the lowest ones were recorded in $2015(203 \mathrm{~mm})$ while in 2016 they were twice higher $(426 \mathrm{~mm})$. On the other hand, average monthly ambient temperatures during the barley vegetation period were similar in respective years. The distribution of precipitation totals and average ambient temperatures in respective months and years of the study are presented in Table 1.

Table 1. Rainfall and air temperature according to the meteorological observatory at Uhrusk

\begin{tabular}{|c|c|c|c|c|c|c|c|}
\hline \multirow{2}{*}{ Year } & \multicolumn{6}{|c|}{ Months } & \multirow{2}{*}{ Total / Mean } \\
\hline & Mar & Apr & May & Jun & Jul & Aug & \\
\hline \multicolumn{8}{|c|}{ Rainfall (mm) } \\
\hline 2015 & 39 & 34 & 62 & 16 & 45 & 7 & 203 \\
\hline 2016 & 52 & 68 & 55 & 66 & 132 & 53 & 426 \\
\hline 2017 & 31 & 60 & 72 & 27 & 100 & 39 & 328 \\
\hline 1963- 2013 & 37 & 45 & 66 & 74 & 86 & 73 & 381 \\
\hline \multicolumn{8}{|c|}{ Air temperature $\left({ }^{\circ} \mathrm{C}\right)$} \\
\hline 2015 & 4.7 & 7.7 & 13.1 & 17.1 & 21.7 & 22.2 & 14.4 \\
\hline 2016 & 3.8 & 9.3 & 14.9 & 18.1 & 20.0 & 18.9 & 14.2 \\
\hline 2017 & 5.8 & 7.4 & 14.2 & 17.9 & 20.1 & 20.1 & 14.3 \\
\hline $1963-2013$ & 2.0 & 8.5 & 14.0 & 17.1 & 19.3 & 18.2 & 13.2 \\
\hline
\end{tabular}




\section{Fertilizers and Plant Protection}

Spring barley of Tocada variety was sown between $1^{\text {st }}$ and $5^{\text {th }}$ April in all study years. Sowing density was 320 seeds per $\mathrm{m}^{-2} .90 \mathrm{~kg}$ of nitrogen fertilizer was applied per ha ${ }^{-1}$ at two dates: before sowing $(60 \mathrm{~kg}$ $\left.\mathrm{N} \mathrm{ha}^{-1}\right)$ and at the tillering stage $\left(30 \mathrm{~kg} \mathrm{ha}^{-1}\right)$. Phosphorus and potassium fertilizers were applied before sowing the barley in respective doses of $30 \mathrm{~kg} \mathrm{P} \mathrm{ha}^{-1}$ and $80 \mathrm{~kg} \mathrm{~K} \mathrm{ha}{ }^{-1}$. The crops were protected against fungal diseases by means of fungicides such as: Alert 375 SC $\left(1.0 \mathrm{~L} \mathrm{ha}^{-1}\right)$ (s.a. flusilazole + carbendazim) at stage 32-33 according to BBCH scale and Tilt Plus 400 EC $\left(1 \mathrm{~L} \mathrm{ha}^{-1}\right)$ (propiconazol + fenpropidin) at $\mathrm{BBCH}$ stage 53-54. Herbicides used for weed control included: Chwastox Trio $540 \mathrm{SL}$ (1.5 L ha-1) (mecoprop + MCPA + dicamba), and Puma Uniwersal 069 EW (fenoxapropP-ethyl ) (1.0 L ha-1) at BBCH stage 23-24.

\section{Features and Statistical Analysis}

The experiment evaluated the following features: 1) grain yield, 2) grain weight per spike, 3) number of spikes per $\mathrm{m}^{-2}$, 4) 1000 grains weight, 5) length of spike, 6) number and air-dry weight of weeds, 7) weeds species composition, 8) economic ratios: gross margin, income from activity, profitability ratio, unit cost, and economic efficiency ratios.

The grains were harvested with a Wintersteiger plot harvester, and grain weight per spike was calculated based on 40 randomly harvested spikes, the number of spikes was determined per $1 \mathrm{~m}^{2}$ of each plot, and the weight of 1000 grains was determined by counting $2 \times 500$ grains. Weed infestation was assessed by botanical-weight method at the stage of wax maturity of barley (83-84 $\mathrm{BBCH})$. The method involved determining the species composition and the number and air-dry weight of weeds per $1 \mathrm{~m}^{2}$ of the plot. The area was selected at random (twice) by means of a $0.5 \mathrm{~m} \times 1.0 \mathrm{~m}$ frame. In order to determine air-dry weight, all weeds were collected from the frame surface, their roots were cut off, and they were placed in a well-ventilated room until their weight became fixed. The results obtained were analysed by statistical methods using one-way analysis of variance (ANOVA) by means of Statistica PL software. In turn, the significance of differences between mean values was verified by means of Tukey's HSD test for $P<0.05$.

\section{Results and Discussion}

Results

\section{Grain Yield and its Components}

Spring barley grain yield was significantly higher (by $25.6 \%$ ) in crop rotation than in cereal monoculture (Table 2). Also, yield was significantly higher under
Table 2. Spring barley grain yield and its components (average from 2015-2017).

\begin{tabular}{|c|c|c|c|c|}
\hline \multirow{2}{*}{ Crop sequence (CS) } & \multicolumn{3}{|c|}{ Tillage systems (TS) } & \multirow{2}{*}{ Mean } \\
\hline & $\mathrm{CT}^{\mathrm{a}}$ & $\mathrm{RT}^{\mathrm{b}}$ & $\mathrm{HT}^{\mathrm{c}}$ & \\
\hline \multicolumn{5}{|c|}{ Grain yield $\left(\mathrm{t} \mathrm{ha}^{-1}\right)$} \\
\hline Crop rotation & 7.18 & 9.01 & 8.31 & 8.17 \\
\hline Cereal monoculture & 6.30 & 7.10 & 4.85 & 6.08 \\
\hline Mean & 6.74 & 8.06 & 6.58 & - \\
\hline \multicolumn{5}{|c|}{$H S D_{0.05}$ for $\mathrm{CS}=0.06, \mathrm{TS}=0.09, \mathrm{CS} \times \mathrm{TS}=0,15$} \\
\hline \multicolumn{5}{|c|}{ Grain weight per spike (g) } \\
\hline Crop rotation & 1.26 & 1.52 & 1.36 & 1.38 \\
\hline Cereal monoculture & 1.18 & 1.26 & 0.91 & 1.12 \\
\hline Mean & 1.22 & 1.39 & 1.14 & - \\
\hline \multicolumn{5}{|c|}{$H S D_{0.05}$ for $\mathrm{CS}=0.04, \mathrm{TS}=0.06, \mathrm{CS} \times \mathrm{TS}=0,10$} \\
\hline \multicolumn{5}{|c|}{ Number of spikes $\left(\mathrm{m}^{2}\right)$} \\
\hline Crop rotation & 568 & 600 & 609 & 592 \\
\hline Cereal monoculture & 534 & 563 & 532 & 543 \\
\hline Mean & 551 & 581 & 571 & - \\
\hline \multicolumn{5}{|c|}{$H S D_{0.05}$ for $\mathrm{CS}=17, \mathrm{TS}=26, \mathrm{CS} \times \mathrm{TS}=\mathrm{ns}$} \\
\hline \multicolumn{5}{|c|}{1000 grains weight $(\mathrm{g})$} \\
\hline Crop rotation & 52.4 & 58.5 & 58.2 & 56.4 \\
\hline Cereal monoculture & 47.0 & 50.3 & 37.1 & 44.8 \\
\hline Mean & 49.7 & 54.4 & 47.6 & - \\
\hline \multicolumn{5}{|c|}{$H S D_{0.05}$ for $\mathrm{CS}=3.1, \mathrm{TS}=4.6, \mathrm{CS} \times \mathrm{TS}=8.2$} \\
\hline \multicolumn{5}{|c|}{ Length of spike $(\mathrm{cm})$} \\
\hline Crop rotation & 7.24 & 7.75 & 7.16 & 7.38 \\
\hline Cereal monoculture & 7.03 & 7.04 & 7.08 & 7.05 \\
\hline Mean & 7.13 & 7.39 & 7.12 & - \\
\hline$H S D_{0.05}$ for $\mathrm{CS}=\mathrm{c}$ & $\mathrm{TS}=0$ & $8, \mathrm{CS}$ & $S=0$. & \\
\hline
\end{tabular}

$\mathrm{CT}^{\mathrm{a}}$ - conventional tillage, $\mathrm{RT}^{\mathrm{b}}$ - reduced tillage, $\mathrm{HT}^{\mathrm{c}}$ - herbicide tillage

RT than under CT and HT, where the difference was respectively $16.4 \%$ and $18.4 \%$. Evaluating the effects of the interaction between CS and TS, it can be stated that in crop rotation the highest yield of barley was recorded under the RT system and the lowest under CT (20.3\% lower). In monoculture the highest yield was also noted for RT and the lowest for HT (31.7\% lower). Also, the components of the yield, i.e., grain weight per spike, number of spikes per $\mathrm{m}^{-2}, 1000$ grains weight, and spike length reached higher values in crop rotation than in monoculture, respectively, by $18.8 \%, 8.3 \%, 20.6 \%$, and $4.5 \%$. Under RT, grain weight per spike, 1000 grains weight, and spike length were significantly higher than under CT and HT, and the number of spikes per $\mathrm{m}^{-2}$ was higher than under CT. The grain yield of barley 


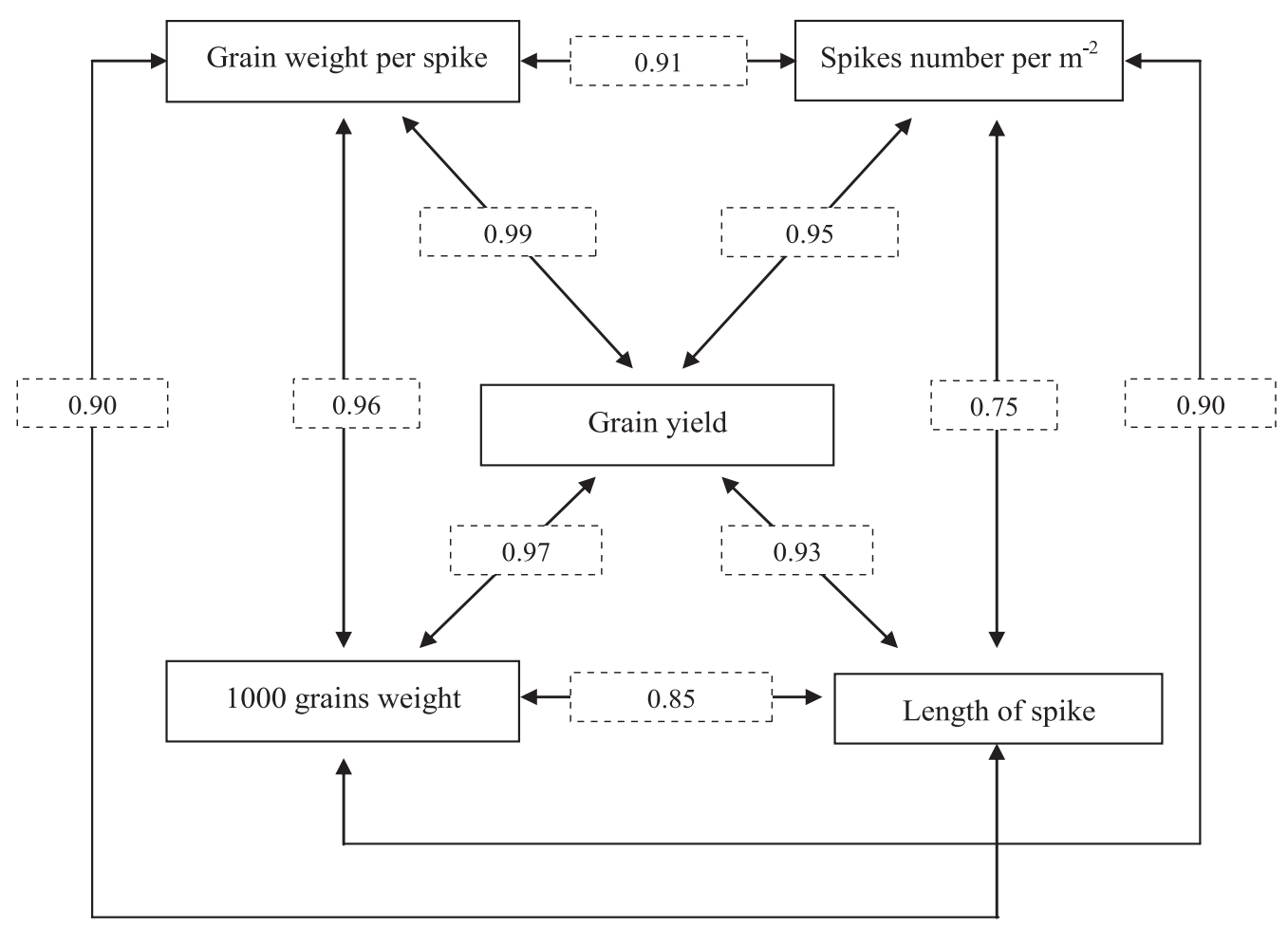

Fig. 1. Straight-line correlation (r) between spring barley grain yield and its components.

was significantly correlated with grain weight per spike, number of spikes per $\mathrm{m}^{-2}, 1000$ grains weight, and spike length (Fig. 1). Significant correlations also occurred between the number of spikes per $\mathrm{m}^{-2}$ and the length of spike, grain weight per spike, and 1000 grains weight and between spike length and grain weight per spike and 1000 grains weight. On the basis of the components of the analysis of variance it can be stated that grain yield and its elements were to a larger extent determined by CS than by TS (Table 3 ).

Table 3. Analysis of variance for grain yield and its components.

\begin{tabular}{|c|c|c|c|c|}
\hline Specification & Value & CS $^{\mathrm{a}}$ & $\mathrm{TS}^{\mathrm{b}}$ & $\mathrm{CS} \times \mathrm{TS}$ \\
\hline \multirow{2}{*}{ Grain yield } & $F$ & 6341.2 & 1272.9 & 817.7 \\
\cline { 2 - 5 } & $P$ & $* *$ & $* *$ & $* *$ \\
\hline \multirow{2}{*}{$\begin{array}{c}\text { Grain weight per } \\
\text { spike }\end{array}$} & $F$ & 232.7 & 76.4 & 37.4 \\
\cline { 2 - 5 } & $P$ & $* *$ & $* *$ & $* *$ \\
\hline \multirow{2}{*}{ Spike number per $\mathrm{m}^{-2}$} & $F$ & 37.6 & 4.8 & 2.9 \\
\cline { 2 - 5 } & $P$ & $* *$ & $*$ & $\mathrm{~ns}$ \\
\hline \multirow{2}{*}{1000 grains weight } & $F$ & 68.1 & 8.2 & 11.9 \\
\cline { 2 - 5 } & $P$ & $* *$ & $* *$ & $* *$ \\
\hline \multirow{2}{*}{\begin{tabular}{c} 
Length of spike \\
\cline { 1 - 5 }
\end{tabular}} & $P$ & $* *$ & $*$ & $*$ \\
\hline
\end{tabular}

$\mathrm{CS}^{\mathrm{a}}$ - crop sequence, $\mathrm{TS}^{\mathrm{b}}$ - tillage system, ${ }^{*} P<0.05$;

$* * P<0.01 ;$ ns - not significant

\section{Weed Infestation Rates}

The number of weeds per $\mathrm{m}^{-2}$ in cereal monoculture was significantly higher than in crop rotation (Table 4). Also, more weeds occurred under RT than under CT and HT systems. Significant differences in this feature were also recorded between CT and HT. Similarly, airdry weight of weeds was higher in cereal monoculture

Table 4. Number and air-dry weight of weeds in spring barley (average from 2015-2017).

\begin{tabular}{|c|c|c|c|c|}
\hline \multirow{2}{*}{ Crop sequence $(\mathrm{CS})$} & \multicolumn{3}{|c|}{ Tillage systems (TS) } & \multirow{2}{*}{ Mean } \\
\hline & $\mathrm{CT}^{\mathrm{a}}$ & $\mathrm{RT}^{\mathrm{b}}$ & $\mathrm{HT}^{\mathrm{c}}$ & \\
\hline \multicolumn{5}{|c|}{ Number of weeds $\left(\mathrm{m}^{2}\right)$} \\
\hline Crop rotation & 6.5 & 13.9 & 10.3 & 10.2 \\
\hline Cereal monoculture & 11.3 & 21.2 & 18.0 & 16.8 \\
\hline Mean & 8.9 & 17.6 & 14.2 & - \\
\hline \multicolumn{5}{|c|}{$H S D_{0.05}$ for $\mathrm{CS}=2.2, \mathrm{TS}=3.1, \mathrm{CS} \times \mathrm{TS}=\mathrm{ns}$} \\
\hline \multicolumn{5}{|c|}{ Air-dry weight of weeds $\left(\mathrm{g} \mathrm{m}^{-2}\right)$} \\
\hline Crop rotation & 18.0 & 31.3 & 23.4 & 24.2 \\
\hline Cereal monoculture & 27.2 & 40.0 & 37.6 & 34.9 \\
\hline Mean & 22.6 & 35.7 & 30.5 & - \\
\hline \multicolumn{5}{|c|}{$H S D_{0.05}$ for $\mathrm{CS}=7.3, \mathrm{TS}=9.1, \mathrm{CS} \times \mathrm{TS}=14.0$} \\
\hline
\end{tabular}

$\mathrm{CT}^{\mathrm{a}}$ - conventional tillage, $\mathrm{RT}^{\mathrm{b}}$ - reduced tillage,

$\mathrm{HT}^{\mathrm{c}}$ - herbicide tillage 
Table 5. Species composition of weeds in spring barley per $\mathrm{m}^{2}$ (average from 2015-2017).

\begin{tabular}{|c|c|c|c|c|c|c|}
\hline \multirow{2}{*}{ Species composition } & \multicolumn{3}{|c|}{ Crop rotation } & \multicolumn{3}{c|}{ Cereal monoculture } \\
\cline { 2 - 7 } & CT & $\mathrm{RT}^{\mathrm{b}}$ & $\mathrm{HT}^{\mathrm{c}}$ & $\mathrm{CT}$ & $\mathrm{RT}$ & $\mathrm{HT}$ \\
\hline Sonchus oleraceus L. & 2.5 & 1.0 & - & 1.5 & - & 2.8 \\
\hline Papaver rhoeas L. & 1.5 & 1.8 & 2.5 & 2.5 & 6.5 & 4.2 \\
\hline Galium aparine L. & 1.5 & 2.2 & - & - & 4.0 & 2.0 \\
\hline Viola arvensis Murray & 0.8 & - & 0.3 & - & - & 1.2 \\
\hline Stellaria media (L.) Vill. & - & 0.2 & - & 0.5 & - & 1.0 \\
\hline Anthemis arvensis L. & - & 1.0 & - & 0.8 & 2.5 & - \\
\hline Amaranthus retroflexus L. & - & - & 0.2 & 0.2 & 1.5 & - \\
\hline Echinochloa crus-galli (L.) P. Beauv. & - & - & 1.8 & - & 2.2 & - \\
\hline Avena fatua L. & - & 4.3 & 3.0 & 2.0 & 2.0 & 2.2 \\
\hline Matricaria inodora L. & - & 0.9 & - & 1.8 & 0.5 & - \\
\hline Fallopia convolvulus (L.) A. Löve & 0.2 & 0.5 & 1.5 & 2.0 & - & 2.4 \\
\hline Galinsoga parviflora Cav. & - & 0.2 & - & - & 0.8 & - \\
\hline Apera spica-venti (L.) P. Beauv. & - & 1.8 & 1.0 & - & 1.2 & 2.2 \\
\hline Number of weed species & 5 & 10 & 7 & 8 & 9 & 8 \\
\hline
\end{tabular}

$\mathrm{CT}^{\mathrm{a}}$ - conventional tillage, $\mathrm{RT}^{\mathrm{b}}$ - reduced tillage, $\mathrm{HT}^{\mathrm{c}}$ - herbicide tillage

than in crop rotation and it was higher under RT than under CT.

Crop sequence in crop rotation and tillage systems differentiated the species composition of weeds (Table 5). Plots under the CT system where barley was sown in crop rotation were most numerously populated by: Sonchus oleraceus, Papaver rhoeas, and Galium aparine; under the RT system - Avena fatua, Galium aparine, Papaver rhoeas, and Apera spica-venti; and under the HT system - Avena fatua, Papaver rhoeas, and Echinochloa crus-galli. In cereal monoculture plots under CT the following species were predominant: Papaver rhoeas, Avena fatua, and Fallopia convolvulus; under RT- Papaver rhoeas, Galium aparine, and Anthemis arvensis; and under HT - Papaver rhoeas, Sonchus oleraceus, and Fallopia convolvulus.

\section{Economic Evaluation of Spring Barley Crops}

A significant aspect of the study was the evaluation of economic effects of spring barley crops depending on the crop sequence system (crop rotation and cereal monoculture) and tillage system (CT, RT, and HT). The highest value of spring barley production was achieved in crop rotation in sites under RT (EUR 1296.4 ha $^{-1}$ ) Table 6. Comparing barley grown in crop rotation and in cereal monoculture, it must be stated that in crop rotation under each tillage system the value of production was higher than in monoculture. Gross margin value pointed to the reasonableness of growing barley in crop rotation under RT. The value was higher respectively by EUR
123.4 per ha-1 and EUR 263.3 per ha- ${ }^{-1}$ than under HT and CT. In monoculture the analyzed economic category assumed lower values than in crop rotation; however, the best values were achieved under the RT system. For each tillage system, the costs of mineral fertilizers accounted for about $56 \%$ of direct costs, while the cost of pesticides was $26 \%$. A significant economic category in the evaluation of production profitability is income from activity calculated as a difference in the value of production and overall costs, taking direct payments into account. The highest production profitability was achieved in crop rotation under the RT system. This method is also recommended on the account of the lowest unit production costs and the profitability ratio amounting to $213.1 \%$. In addition, the best solution in terms of economy was using Roundup 360 SL herbicide under the HT system, and at the same time reducing the costs as a result of lower consumption of fuel than under the CT system (Table 6).

The gross margin and income from activity are supplemented by economic efficiency ratios pointing to the existence of relationships between the analyzed variables (Table 7). Ratio A, determining the amount of direct costs of producing 1 ton of barley grain, testifies to the advantage of RT over CT and HT. This variant generated the lowest direct cost per 1 ton of main product, that is, €38.98. In monoculture, under each tillage system this ratio was higher than in crop rotation, which suggests that this method is more capital-consuming. Ratios $\mathrm{B}$ and $\mathrm{C}$ indicate large differences between the analyzed variants. 
Table 6. Selected economic categories per 1 ha of spring barley under different tillage systems.

\begin{tabular}{|c|c|c|c|c|}
\hline \multirow{2}{*}{ Crop sequence (CS) } & \multicolumn{3}{|c|}{ Tillage systems (TS) } & \multirow{2}{*}{ Mean } \\
\hline & $\mathrm{CT}^{\mathrm{a}}$ & $\mathrm{RT}^{\mathrm{b}}$ & $\mathrm{HT}^{\mathrm{c}}$ & \\
\hline \multicolumn{5}{|c|}{ Value of output $\left(\mathrm{EUR} \mathrm{ha}^{-1}\right)$} \\
\hline Crop rotation & 1033.1 & 1296.4 & 1195.7 & 1175.5 \\
\hline Cereal monoculture & 906.5 & 1021.6 & 697.8 & 874.8 \\
\hline Mean & 969.8 & 1159.7 & 946.7 & - \\
\hline \multicolumn{5}{|c|}{ Gross margin (EUR ha-1) } \\
\hline Crop rotation & 676.8 & 940.1 & 816.7 & 819.3 \\
\hline Cereal monoculture & 550.2 & 665.3 & 318.9 & 518.6 \\
\hline Mean & 613.5 & 803.5 & 567.8 & - \\
\hline \multicolumn{5}{|c|}{ Net income with direct payments (EUR ha-1) } \\
\hline Crop rotation & 522.2 & 800.0 & 681.3 & 667.8 \\
\hline Cereal monoculture & 395.6 & 525.2 & 183.5 & 368.1 \\
\hline Mean & 458.9 & 662.6 & 432.4 & - \\
\hline \multicolumn{5}{|c|}{ Unit cost $\left(E U R t^{-1}\right)$} \\
\hline Crop rotation & 87.2 & 67.5 & 75.1 & 76.6 \\
\hline Cereal monoculture & 99.4 & 85.7 & 128.7 & 104.6 \\
\hline Mean & 93.3 & 76.6 & 101.9 & - \\
\hline \multicolumn{5}{|c|}{ Profitability ratio $(\%)$} \\
\hline Crop rotation & 165.0 & 213.1 & 191.6 & 189.9 \\
\hline Cereal monoculture & 144.8 & 167.9 & 111.8 & 141.5 \\
\hline Mean & 154.9 & 190.5 & 151.7 & - \\
\hline
\end{tabular}

$\mathrm{CT}^{\mathrm{a}}$ - conventional tillage, $\mathrm{RT}^{\mathrm{b}}$ - reduced tillage,

$\mathrm{HT}^{\mathrm{c}}$ - herbicide tillage

The difference between the value of production per $€ 1$ of direct costs in the variant with the highest (RT in crop rotation) and the lowest (CT in crop rotation) levels of the ratio in the analyzed period was on average $€ 12.98$. Gross margin per tonne of the main product also points to a clear advantage of the RT system in crop rotation. The profitability of crop growing depends on the yield, production costs, and grain prices. For this reason, the analysis takes into account the ratio expressing the relationship between the selling prices of barley grain and unit cost (D). The most advantageous relationship is observed, likewise for previously mentioned ratios, with reference to the RT system, where the price was twice higher than the unit production cost. Income from activity per 1 ton of grain (E) ranged from $€ 88.79$ (RT) to $€ 72.73$ (CT) for crop rotation, and from $€ 73.97$ (RT) to $€ 37.83$ (HT) for monoculture. Direct payments had a significant impact on the level of income from the cultivation of barley. Their income share increased along with reduction in the level of income from activity (Table 7).

\section{Discussion}

As a rule, crop productivity in crop rotation is considerably higher than in monoculture, which is due to the fact that in crop rotation the yield-forming possibilities of the habitat, elements of agricultural engineering (fertilization, tillage, plant protection), and the yield-forming potential of crops are utilized in an effective manner [2, 6]. In crop rotation, the plants make much better use of nutrients from fertilizers and soil and are more competitive to weeds, fungal pathogens, and pests. However, more and more often for various reasons (organizational, economic, structural) multispecies crop rotation is abandoned in favour of crop sequence involving 2-3 species of cereal plants or cereal and industrial plants as well as in favour of cereal monocultures. Such a situation leads to an intensified occurrence of agrophages, which in turn necessitates using more pesticides. According to Woźniak and Soroka [13] and Shahzad et al. [10], cereal monoculture leads to increased infestation with weeds and, as a consequence, a decrease in yield. Also in our studies we found an increased number and mass of weeds in cereal monoculture as compared to crop rotation. In addition, grain yield was reduced by $25.6 \%$ in comparison to crop rotation. Barley grain yield and the field's weed infestation rate are also determined by the tillage system [10-11]. In our studies grain yield was 16.4-18.4\% higher under RT than under CT and HT. Studies carried out by Woźniak and Kwiatkowski [8] showed that higher barley yield was obtained under conventional tillage rather than under reduced tillage, although they found the highest number and biomass of weeds in the study site. Similarly, in our studies RT plots were more infested with weeds than CT and HT plots, whereas the highest rate of weed infestation was recorded in monoculture on RT plots. However, it is important that most weeds occurred only in the barley maturing period, that is, in the second half of the vegetation period, whereas their number and biomass could not be a hazard to barley. On the other hand, weeds that occurred in the first part of the vegetation period, that is, after the emergence of barley, were effectively eliminated by herbicides.

The decision about which grain cultivation method should be used is determined not only by natural conditions or intended quality results but also by economic factors [18-19]. Expenditure connected with the tillage system and the effects of tillage are important elements affecting the profitability of growing crops [20]. Direct production costs (seed material, fertilizers, pesticides, crop insurance) play a special role. These costs are proportionally related to production scale and they have a direct impact on the volume and value of production [21]. Mineral fertilizers have the highest share in the structure of direct costs. As recounted by Nasalski [22], such fertilizers account for $46 \%$ of the direct costs of growing spring barley. In our studies, 
Tabela 7. Economic efficiency ratios per 1 ha of spring barley under different tillage systems.

\begin{tabular}{|c|c|c|c|c|c|c|}
\hline \multirow{2}{*}{ Ratios } & \multirow{2}{*}{ Crop sequence (CS) } & \multirow{2}{*}{$\begin{array}{c}\text { Unit of meas- } \\
\text { ure }\end{array}$} & \multicolumn{3}{|c|}{ Tillage systems (TS) } & \multirow{2}{*}{ Mean } \\
\hline & & & $\mathbf{C T}^{\mathbf{a}}$ & $\mathbf{R T}^{\mathbf{b}}$ & $\mathbf{H T}^{\mathrm{e}}$ & \\
\hline \multirow{3}{*}{ A } & Crop rotation & \multirow{3}{*}{$\mathbf{E U R ~ t}^{-1}$} & 48.91 & 38.98 & 45.44 & 44.44 \\
\hline & Cereal monoculture & & 55.74 & 49.46 & 77.85 & 61.02 \\
\hline & Mean & & 52.33 & 44.22 & 61.65 & - \\
\hline \multirow{3}{*}{ B } & Crop rotation & \multirow{3}{*}{ EUR } & 2.94 & 15.93 & 13.66 & 10.84 \\
\hline & Cereal monoculture & & 11.14 & 12.55 & 7.97 & 10.55 \\
\hline & Mean & & 7.04 & 14.24 & 10.82 & - \\
\hline \multirow{3}{*}{$\mathrm{C}$} & Crop rotation & \multirow{3}{*}{$\mathbf{E U R}^{-1}$} & 94.27 & 104.34 & 98.28 & 98.96 \\
\hline & Cereal monoculture & & 87.34 & 93.71 & 65.75 & 82.26 \\
\hline & Mean & & 90.80 & 99.03 & 82.01 & - \\
\hline \multirow{3}{*}{$\mathrm{D}$} & Crop rotation & \multirow{3}{*}{ EUR } & 1.65 & 2.13 & 1.92 & 1.90 \\
\hline & Cereal monoculture & & 1.45 & 1.68 & 1.12 & 1.42 \\
\hline & Mean & & 1.55 & 1.91 & 1.52 & - \\
\hline \multirow{3}{*}{$\mathrm{E}$} & Crop rotation & \multirow{3}{*}{$\mathbf{E U R ~ t}^{-1}$} & 72.73 & 88.79 & 81.98 & 81.17 \\
\hline & Cereal monoculture & & 62.79 & 73.97 & 37.83 & 58.20 \\
\hline & Mean & & 67.76 & 81.38 & 59.91 & - \\
\hline \multirow{3}{*}{$\mathrm{F}$} & Crop rotation & \multirow{3}{*}{$\%$} & 20.38 & 13.30 & 15.62 & 16.43 \\
\hline & Cereal monoculture & & 26.90 & 20.26 & 58.01 & 35.06 \\
\hline & Mean & & 23.64 & 16.78 & 36.81 & - \\
\hline
\end{tabular}

$\mathrm{CT}^{\mathrm{a}}$ - conventional tillage, $\mathrm{RT}^{\mathrm{b}}$ - reduced tillage, $\mathrm{HT}^{\mathrm{c}}$ - herbicide tillage

Ratios shown in the table: A - Direct costs per 1 tonne of main product; B - Total output per 1 EUR of direct costs; C - Gross margin per 1 tonne of main product; D - Grain selling price to unit cost of production; E - Net income with direct payments per 1 tonne of grain; F - Share of direct payments in net income

Source: Own calculations

the share was even higher and for each tillage system and corresponded to more than $50 \%$ of all direct costs. Winnicki et al. [23] achieved similar results. Gross margin is an economic category used for evaluating the profitability of production, and for comparing farms, production systems or production technologies [24]. It is the value of production less direct costs of such production and it allows us to select the crop-growing variant that is the best from the point of view of the economy. The plots where barley was grown by crop rotation, and in particular under the RT system, had a clear advantage in terms of production profitability over other sites. Also, the results achieved by Kovacev et al. [25] confirm the positive impact of tillage technologies limiting the number of treatments on the profitability of crop production. It reduces the consumption of fuel and, as a consequence, decreases the cost of production. In the analyzed experiment, fuel consumption under the RT system, which was characterized by the highest level of profitability, was $32 \%$ lower than under the CT system.

\section{Conclusions}

In market economy conditions, decisions regarding the selection of a tillage system are primarily based on expenditure and effects. Considering the significance of both production and economic and environmental effects of the production process, the aim of our study was to evaluate different tillage systems used for sowing spring barley in crop rotation and cereal monoculture in terms of their productivity and economic aspects. The analysis of results showed a clear competitive advantage of growing barley in crop rotation over cereal monoculture. This was determined by the production results and, in particular, a significantly higher barley grain yield. From an economic point of view, the advantage was caused by the profitability of production being relatively higher. Among the evaluated tillage systems, the best productivity and economic effects were observed for RT in crop rotation. That system generated the highest yield and the best yield component values. The above-mentioned spring barley growing variant is also recommended with regard to the relatively high values of economic ratios used in the evaluation. 


\section{Conflict of Interest}

The authors declare no conflict of interest.

\section{References}

1. NEVENS F., REHEUL D. Crop rotation versus monoculture; yield, $\mathrm{N}$ yield and ear fraction of silage maize at different levels of mineral $\mathrm{N}$ fertilization. Netherlands Journal of Agriculture Science, 49 (4), 405, 2001.

2. WOŹNIAK A. Yield and chemical composition of spring triticale grain depending on cropping and tillage systems. International Journal of Plant Production, 10 (1), 45. 2016.

3. JASKULSKI D., KOTWICA K., JASKULSKA I., PIEKARCZYK M., OSIŃSKI G., POCHYLSKI B. Components of today's tillage and crop farming systems - production and environmental effects. Fragmenta Agronomica, 29 (3), 61. 2012 [In Polish].

4. HERNANDEZ-RESTREPO M., GROENEWALD J.Z., ELLIOTT M.L., CANNING G., MCMILLAN V.E., CROUS P.W. Take-all or nothing. Studies in Mycology, 83, 19, 2016.

5. WOŹNIAK A., KAWECKA-RADOMSKA M. Crop management effect on chemical and biological properties of soil. International Journal of Plant Production, 10 (3), 391. 2016.

6. DEIKE S., PALLUTT B., MELANDER B., STRASSEMEYER J., CHRISTEN O. Long-term productivity and environmental effects of arable farming as affected by crop rotation, soil tillage intensity and strategy of pesticide use: A case-study of two long term field experiments in Germany and Denmark. European Journal of Agronomy, 29 (4), 191, 2008.

7. CHAUHAN B.S., SINGH R.G., MAHAJAN G. Ecology and management of weeds under conservation agriculture: a review. Crop Protection, 38, 57, 2012.

8. WOŹNIAK A., KWIATKOWSKI C. Effect of longterm reduced tillage on yield and weeds of spring barley. Journal of Agricultural Science and Technology, 15(20), 1335, 2013.

9. LAHMAR R. Adoption of conservation agriculture in Europe lesson of the KASSA project. Land Use Policy, 27 (1), 4, 2010.

10. SHAHZAD M., FAROOQ M., JABRAN K., HUSSAIN M. Impact of different crop rotations and tillage systems on weed infestation and productivity of bread wheat. Crop Protection, 89, 161, 2016.

11. DE VITA P., DI PAOLO E., FECONDO G., DI FONZO N., PISANTE, M. No-tillage and conventional tillage effects on durum wheat yield, grain quality, and soil moisture content in Southern Italy. Soil and Tillage Research, 92 (1-2), 69, 2007.

12. MONTEMURRO F., MAIORANA M. Cropping systems, tillage and fertilization strategies for durum wheat performance and soil properties. International Journal of Plant Production, 8 (1), 51, 2014.
13. WOŹNIAK A., SOROKA M. Structure of weed communities occurring in crop rotation and monoculture of cereals. International Journal of Plant Production, 9 (3), 487, 2015.

14. PARYLAK D., PYTLARZ E. Effects on production of winter wheat in monoculture under reduced Tillage. Fragmenta Agronomica, 30 (4), 114, 2013 [In Polish].

15. NEUMANN A., SCHMIDTKE K., RAUBER R. Effects of crop density and tillage system on grain yield and $\mathrm{N}$ uptake from soil and atmosphere of sole and intercropped pea and oat. Field Crops Research, 100, 285, 2007.

16. RÜHLEMANN L., SCHMIDTKE K., BELLINGRATHKIMURA S.D. Short-term effects of differentiated tillage on dry matter production and grain yield of autumn and spring sown grain legumes grown monocropped and intercropped with cereal grains in organic farming. Plant Prod. Sci. 18 (1), 76, 2015.

17. IUSS Working Group WRB. World Reference Base for Soil Resources 2014, update 2015. International soil classification system for naming soils and creating legends for soil maps. World Soil Resources Reports No. 106. FAO, Rome, 2015.

18. KRASOWICZ S. The role of economic evaluation in agricultural research. Journal of Agribusiness and Rural Development, 2 (12), 93, 2009. [In Polish].

19. ŻUK-GOłASZEWSKA K., TRUSZKOWSKI W., WINNICKI T. Possibilities for improvement of economic and energetic effectiveness of spring barley production depending on nitrogen fertilization level. Acta Scientiarum Polonorum, Agricultura 9 (3), 97, 2010.

20. OLEKSY A., SZMIGIEL A., KOŁODZIEJCZYK M. Effect of cultivation intensity on protein concentrations and its yield of the winter wheat cultivars. Acta Scientiarum Polonorum, Agricultura, 7 (1), 47, 2008 [In Polish].

21. SKARŻYŃSKA A. Technical, economic and environmental efficiency of production of selected plant products in the agricultural Polish regions. Problems of Agricultural Economics, 1(350), 117, 2017.

22. NASALSKI Z., SADOWSKI T., RYCHCIK B., RZESZUTEK I. Comparison of effectiveness of winter and spring barley cropping after potato. Acta Scientiarum Polonorum, Agricultura, 3 (1), 99, 2004. [In Polish].

23. WINNICKI T., ŻUK-GOŁASZEWSKA K., TRUSZKOWSKI W. Economic and energy efficiency of spring barley cultivation in relation to plant protection application. Acta Scientiarum Polonorum, Agricultura 12 (4), 105, 2013.

24. FIRTH CH. The use of gross and net margins in the economic analysis of organic farms In. Powell et al. (eds), UK Organic Research 2002: Proceedings of the COR Conference, 26-28 ${ }^{\text {th }}$ March 2002, Aberystwyth, 285-288, 2002.

25. KOVACEV I., KOSUTIC S., FILIPOVIC D., POSPISIL M., COPEC K. Economic efficiency of non-conventional soil tillage systems in oil seed rape and winter barley production. Book Series: Actual Tasks on Agricultural Engineering, Zagreb, 39, 271, 2011. 